\title{
Comparison between the efficacy of metronidazole vaginal gel and Berberis vulgaris (Berberis vulgaris) combined with metronidazole gel alone in the treatment of bacterial vaginosis
}

\author{
Mansoure Masoudi ${ }^{1}$, Mahmoud Rafieian Kopaei², Sepideh Miraj ${ }^{3}$
}

${ }^{1}$ Resident of Gynecology, Faculty of Medicine, Shahrekord University of Medical Sciences, Shahrekord, Iran

${ }^{2}$ Ph.D. of Pharmacology, Full Professor, Cellular and Molecular Research Center, Shahrekord University of Medical Sciences, Shahrekord, Iran

${ }^{3}$ M.D., Gynecologist, Fellowship of Infertility, Assistant Professor, Faculty of Medicine, Shahrekord University of Medical Sciences, Shahrekord, Iran

\section{Type of article: Original}

\begin{abstract}
Background: Bacterial vaginosis is one of the most prevalent complications among reproductive-aged women. Antibacterial and antifungal effects of Berberis vulgaris have been demonstrated in vitro and in vivo.

Objectives: This study aimed to compare the therapeutic effects of the vaginal gel of Berberis vulgaris 5\% (in metronidazole base) with metronidazole vaginal gel $0.75 \%$ on bacterial vaginosis on 80 patients referred to the Hajar Hospital from January 2012 to April 2013.

Methods: This study was a randomized clinical trial research on 80 women affected by bacterial vaginosis, who were randomly divided into two groups of 40 participants. Diagnostic criteria were Amsel's criteria and Gram stain. Berberis vulgaris 5\% (in metronidazole gel base) or metronidazole vaginal gel for five-night usage was prescribed to each group, and after two to seven days therapeutic effects and Amsel criteria were assessed. Data analysis was performed by SPSS 16 using Student t-test, chi-square, and ANOVA tests.

Results: Findings of the study showed a statistically significant difference with regard to treatment response between the study groups $(\mathrm{p}<0.001)$, and the Berberis vulgaris group had a better response than the metronidazole gel group. The patients in groups of Berberis vulgaris in a metronidazole gel base did not experience any relapse, but, in the metronidazole group, $30 \%$ of patients experienced relapse during three weeks' follow-up.

Conclusions: Findings of the study showed that adding Berberis vulgaris fruit extract on metronidazole improve the efficacy of bacterial vaginosis therapy.

Clinical trial registration: The trial was registered at the Iranian Registry of Clinical Trials (http://www.irct.ir) with the IRCT ID: IRCT201411102085N13.

Funding: Shahrekord University of Medical Sciences supported this research.

Keywords: Berberis vulgaris, Metronidazole, Vaginosis
\end{abstract}

\section{Introduction}

Vaginal disorders such as vaginal discharge, itching, and bad smell occur in most women during their lifetime (1). These symptoms cause problems in women, and eventually they tend to treat and cure these problems $(2,3)$. Vaginitis was shown in three types of infection: bacterial vaginosis, trichomoniasis, and vulvovaginal candidiasis (4). Among them, bacterial vaginosis (BV) is the most common cause of vaginal discharge in women of reproductive age and is the most common vaginal infection in the world (1). Bacterial vaginosis is a change in the normal vaginal flora, thus decreasing the hydrogen-peroxidase-producing lactobacilli and often causing an overgrowth of anaerobic bacteria (5). Etiology of bacterial vaginosis is not clear, but it is associated with the replacement of Lactobacillus bacteria in the vagina with other bacteria such as Gardenella vaginalis, ureaplasma, Mycoplasma hominis, mobiluncus, and other bacteria $(1,6,7)$. Normally, lactic acid, hydrogen peroxide, and

\section{Corresponding author:}

Assistant Professor Dr. Sepideh Miraj, Faculty of Medicine, Shahrekord University of Medical Sciences, Shahrekord, Iran. Tel: +98.9126509952, Fax: +98.32225456, Email: miraj.sepide@gmail.com

Received: April 03, 2016, Accepted: July 01, 2016, Published: August 2016 iThenticate screening: July 01, 2016, English editing: July 24, 2016, Quality control: August 03, 2016

(C) 2016 The Authors. This is an open access article under the terms of the Creative Commons Attribution-NonCommercialNoDerivs License, which permits use and distribution in any medium, provided the original work is properly cited, the use is non-commercial and no modifications or adaptations are made. 
bacitracin are produced by Lactobacillus and help the vagina to keep its acidic PH and thus protect against infections caused by microorganisms $(8,9)$. Bacteria are responsible for producing bacterial vaginosis produce enzymes that remove protective layer (gel layer) of epithelium of vagina and cervix (8). The anaerobic produce inflammatory proteins as well as accompany pregnancy complications such as preterm delivery, pelvic inflammatory disease, endometritis, post-surgical gynecologic infections, gonorrhea, and clamidia trachomatis $(1,6,10)$. Risk factors for bacterial vaginosis are to use an IUD, have numerous sex partners, have a new sex partner, to use condoms inappropriately, to smoke, etc. (3,11-13). Consumption of oral contraceptives is inversely associated with the risk of bacterial vaginosis (10). The most common symptoms of bacterial vaginosis is a foul-smelling vaginal discharge (1, 10 ), which reduces the activity and performance of women in society and affects their sexual life (14). Clinical examination show a gray, diluted, and homogenized discharge that covers the vaginal wall and smells like fish (12, 15). The treatment of bacterial vaginosis is basically the use of topical or systemic antibiotics with an effect on anaerobic organisms not having any impact on normal vaginal lactobacilli. Of the antibiotics used are metronidazole and clindamycin (16). In addition to these cases, an acidic vaginal environment helps lactobacilli colonization and prevention of anaerobic growth (17). In addition, the use of antiseptics and probiotics also are effective in the treatment of bacterial vaginosis (16). Among them, metronidazole has been effective for more than 45 years as a treatment for infections such as for abdominal, gynecologic, and systemic infections (18). Metronidazole is a drug with high performance against anaerobic and with weak performance against lactobacilli; it is the drug of choice for BV. The drug is metabolized in the liver. Side effects of metronidazole are mild to moderate. Most problems associated with consumption of this drug are related to the patient's digestive system. Its serious and rare complications include seizures and peripheral neuropathy characterized by numbness and paresthesia in extremities, which have been observed in long-term treatment (18). The use of metronidazole can cause side effects such as darkening of the urine, drowsiness, metallic taste in the mouth, dizziness, nausea, transient decrease in blood neutrophils, Disulfiram reaction with alcohol, peripheral neuropathy, and vaginal candidiasis as well as diarrhea and vomiting and, rarely, pancreas inflammation (both in oral as well vaginal forms). In addition, in the event of rare cases, allergies or drug resistance to metronidazole may be observed. Many physicians prefer vaginal treatment to oral therapy due to avoidance of systemic side effects such as mild to moderate gastrointestinal problems and bad taste of drugs (19). In recent years, the consumption of herbal drugs has increased due to the interest in herbal medicines and side effects of chemical drugs. Research results also showed good effects in the treatment of various diseases, including bacterial disorders $(20,21)$, parasitic morbidities $(22,23)$, and cancer $(24)$. Of the various plants that have received significant attention and research is Berberis vulgaris. Berberis vulgaris or Berberis vulgaris $\mathrm{L}$ belongs to the Berberidaceae family. Its shrub has a height of 1.5 to 3 meters, yellow twigs and branches are often raised with veined thistle, usually three branches, which each 6 to $18 \mathrm{~mm}$. Berberine has anticonvulsant, sedative, and diuretic effects. Oxycontin chloride $0.01 \%$ and clumbamin chloride $1 \%$ kills bacillus subtilis, while berberine sulfate is anti-amoeba and tribumanuma (25). Given the high prevalence of bacterial vaginosis and problems of existing treatment such as side effects of metronidazole and tendency of people to use traditional therapies, along with the use of medicinal plants and properties of Berberis vulgaris, the aim of the present study was to compare the effects of metronidazole vaginal gel and Berberis and metronidazole gel alone in the treatment of recurrent bacterial vaginosis in women referred to women clinics of the Hajar Hospital in 2013.

\section{Material and Methods}

\subsection{Trial design and participants}

This study was a randomized clinical trial conducted from April 2014 to September 2015. This clinical trial was conducted in an Iranian governmental educational hospital (Hajar Hospital). This hospital is affiliated with Shahrekord University of Medical Sciences, and it is the referral center of the Obstetrics and Gynecology Clinic. The study population was selected among the patients hospitalized in the Hajar Hospital in Shahrekord with bacterial vaginosis aged 18 to 40 years old referred to the Hajar hospital from January 2012 to April 2013.

\subsection{Selection criteria}

\subsubsection{Inclusion criteria:}

The diagnosis of BV was based on Gram staining and Amsel's criteria. Having three positive criteria of four Amsel's criteria were considered as BV (16):

1) Thin homogeneous white or gray vaginal discharge

2) Positive whiff test

3) More than $20 \%$ of clue cells in the wet smear of vagina

4) Vaginal PH more than 4.5 
Inclusion criteria were diagnosis of BV based on Amsel's criteria and married women aged between 18 to 40 years with a willingness to participate in the study.

\subsubsection{Exclusion criteria:}

Exclusion criteria were use of systemic or local antibiotics in the past two weeks, post-menopausal women, pregnancy, virgin, hysterectomy, spotting, pelvic infection, sperm in smear, diseases such as diabetes and immune deficiency, and sensitivity to Berberis vulgaris.

\subsection{Interventions}

The researcher explained the goals and methods of the study to the patients who also signed an informed consent form. All patients could withdraw from the study at any time and for any reason. Patients in different groups were treated for five nights in the following way: Group A vaginal gel of Berberis vulgaris $5 \%$ in a metronidazole base, and Group B: vaginal gel of metronidazole $0.75 \%$ alone. Two to seven days after treatment, patients were evaluated for response again. To isolate the bacteria Gardenella vaginalis from clinical specimens, discharge on the twin 80 HBT, the human blood bilayers were cultured, an antibiogram of the isolated bacteria was performed, and the efficacy of fruit extract of Berberis vulgaris on culture environment was assessed. In order to increase the precision of the study, the experiments were repeated three times. The fruit of Berberis vulgaris from Mashhad (northeast of Iran) was collected. The extraction method was percolation with ethanol $70 \%$. The prepared extract of Berberis vulgaris was added to metronidazole as the basis in a concentration of $5 \%$ by a pharmacologist. Prepared gels were filled in special tubes with the same shape and certain code. The antioxidant properties of Berberis vulgaris extracts were determined by DPPH method, which was used by Rabiei and colleagues (19). In order to determine the minimum inhibitory concentration (MIC) of the extract, $20 \mathrm{mg}$ of extract was dissolved in $1 \mathrm{ml}$ saline normal, then different dilutions in saline normal $(1.25,2.5,5,10$, and 20) were prepared. In the next step, a loop of bacterial suspension was added into the Butylated hydroxytoluene (BHT) and incubated for four hours in $37^{\circ} \mathrm{C}$. Finally, the dilution was inoculated in sterile condition in methylene blue agar medium for 24 hours in $37^{\circ} \mathrm{C}$ and evaluated for antibacterial activity. Patients were forbidden from vaginal washing, intercourse, and using any vaginal medication during treatment. The lack of four Amsel's criteria or the presence of only one criterion of Amsel was indicator of the treatment's achievement or failure (27). Patients who did not improve after seven days of treatment completion were referred for treatment with oral metronidazole. Antioxidant activity of Berberis vulgaris was carried out by Rabii and his colleague's method using DPPH (28). To prepare the extract, maceration was used. For this purpose, 5 $\mathrm{g}$ of Berberis vulgaris was transferred to Erlenmeyer flasks, and $10 \mathrm{ml}$ of distilled water was added to it and steeped in laboratory temperature for 24 hours; then we use the flat Whatman paper and liquid water for examination with the help of machine vacuum distillation condensed and incubated at $37^{\circ} \mathrm{C}$ for 24 hours, the plates were stored. Each individual stocks of extract and BHT was dissolved separately with the concentration of $1 \mathrm{mg} / \mathrm{ml}$ and DPPH with concentration of $0.1 \mathrm{mM}$ (all in the ethanol). Using Stoke achieved, six concentrations between $5 \mu \mathrm{g}$ to $100 \mu \mathrm{g}$ were prepared including 10,20,40,60,80,100 in a volume of $2 \mathrm{ml}$ and six extract concentrations were prepared the same way for BHT. Two ml of DPPH was added to each of the six concentration of extract or BHT and placed in the darkness for 15 minutes. The control tube containing only $2 \mathrm{ml}$ of ethanol and two $\mathrm{ml}$ of DPPH were prepared alongside of the specimens. After 15 minutes, a spectrophotometer at a wavelength of $517 \mathrm{~nm}$ with zero ethanol Blank and samples were read and absorbed. The plotted concentration at which $50 \%$ of DPPH radicals was neutral that the $\mathrm{x}$ axis was extract concentration and $\mathrm{y}$ axis was inhibition concentration. The concentration at which $50 \%$ of DPPH was neutral was reported IC50 as the $\mathrm{mg}$ of dry extract or $\mathrm{mM}$ of antioxidant substance or number of neutralized DPPH molecules per molecule of antioxidant.

\subsection{Outcomes}

The primary outcomes of our analyses were the mean age, age at menarche, age at marriage, number of pregnancies, number of labors and abortions. Also, the secondary outcomes from the analyses infection, the number of infections, medical treatment, hospitalization, and home treatment of infection.

\subsection{Sample size}

The sample size was calculated to be 80 subjects. This sample size was calculated by assuming the test power of $80 \%$ and a confidence level of $95 \%$ and using the following formula: $n=\left(Z_{1-\alpha / 2}+Z_{1-\beta}\right)^{2}\left[P_{1}\left(1-P_{1}\right)+P_{2}\left(1-P_{2}\right)\right] /\left(P_{1-}\right.$ $\left.\mathrm{P}_{2}\right)^{2}$, where $\mathrm{n}=$ sample size; $\mathrm{Z}_{1-\alpha / 2}=1.96$ when $\alpha=5 \%$ for two-sided test; $\mathrm{Z}_{1-\beta}=0.842$ when $\beta=20 \%$ (test power $=$ $80 \%$ ); and $\mathrm{P}=$ probability of the main outcome. 


\subsection{Randomization and blinding}

Patients and physicians were not informed of the Drug Code. Randomization was done using the coded papers. The patients in each group were matched in terms of age, education, parity, and contraceptive methods (40 in each group).

\subsection{Statistical methods}

Data were analyzed by SPSS software (version 16; SPSS, Chicago, IL) using independent samples t-test, ANOVA, Tukey tests, and chi-square tests. P-value less than 0.05 was considered significant.

\subsection{Research ethics}

The proposal for this thesis research was presented to the Ethics Committee of Shahrekord University of Medical Sciences after its scientific approval by the Obstetrics and Gynecology Department. The study was conducted in agreement with the Declaration of Helsinki and its subsequent revisions and in accordance with local Institutional Review Board recommendations. The Ethics Committee approved the study with No. 92-6-33. The authors confirm that all ongoing and related trials for this drug/intervention are registered. The participants were informed about the objective and nature of the study, and each participant provided her written consent in her native language (Persian) prior to the study. Also, we were committed to keeping all of the participants' information confidential.

\section{Results}

In this study, 80 married women participated with an average age of $32.88 \pm 6.04$ years old with age range of 19 to 40 years old. In each group, 40 married women with one partner participated. Most women (92.5\%) preferred to use one of the prevention methods of these natural way (34.2\%), and no significant difference was observed between groups $(\mathrm{p}=0.76) 90.8 \%$ of participants had a history of vaginal infection and $90.5 \%$ of them received previous treatment using medical methods. Among the samples, $27.5 \%$ had a history of home treatment and only $5 \%$ of the people had a history of hospitalization due to infection. The mean age, age at menarche, age at marriage, number of pregnancies, number of labors and abortions were studied in groups, and no significant difference was observed between them. Chi-square test showed that education and employment status in the two groups were the same (Table 1).

Table 1. Individual characteristics of participants in two groups under study

\begin{tabular}{|c|c|c|c|c|}
\hline \multicolumn{2}{|l|}{ Variable } & Metronidazole & $\begin{array}{l}\text { Berberis vulgaris at the base of } \\
\text { metronidazole }\end{array}$ & $\begin{array}{l}p \text { - } \\
\text { value }\end{array}$ \\
\hline \multicolumn{2}{|c|}{ Age (mean and standard deviation) } & $6.38 \pm 48.32$ & $96.6 \pm 75.32$ & 0.85 \\
\hline \multicolumn{2}{|c|}{ Menarche age (mean and standard deviation) } & $1.13 \pm 45.13$ & $1.05 \pm 13.62$ & 0.47 \\
\hline \multicolumn{2}{|c|}{ Marriage age (mean and standard deviation) } & $4.21 \pm 20.25$ & $3.73 \pm 19.02$ & 0.17 \\
\hline \multicolumn{2}{|c|}{$\begin{array}{l}\text { Number of pregnancies (mean and standard } \\
\text { deviation) }\end{array}$} & $1.31 \pm 2.18$ & $1.94 \pm 2.32$ & 0.68 \\
\hline \multicolumn{2}{|c|}{ Number of labors (mean and standard deviation) } & $1.30 \pm 2.05$ & $1.80 \pm 1.92$ & 0.72 \\
\hline \multicolumn{2}{|c|}{$\begin{array}{l}\text { Number of abortions (mean and standard } \\
\text { deviation) }\end{array}$} & $0.54 \pm 0.25$ & $0.65 \pm 0.32$ & 0.57 \\
\hline \multirow{2}{*}{$\begin{array}{l}\text { Employment status (frequency, } \\
\text { percentage) }\end{array}$} & Employed & 4 & 8 & \multirow[t]{2}{*}{0.21} \\
\hline & Unemployed & 36 & 32 & \\
\hline \multirow[t]{3}{*}{ Education } & Illiterate & 2 & 3 & \multirow[t]{3}{*}{0.18} \\
\hline & Undergraduate & 19 & 11 & \\
\hline & Graduated & 19 & 26 & \\
\hline
\end{tabular}

The two groups did not have any significant difference in terms of infection, the number of infections, medical treatment, hospitalization, and home treatment of infection. Chi-square test showed no significant differences in clinical symptoms of bacterial vaginosis at the baseline between the groups, so the groups were similar in terms of clinical symptoms (Table 2). The t-test was shown in which the two groups were significantly different in terms of improvement $(p<0.001)$. Overall, the results showed that the combination of Berberis vulgaris and metronidazole in the treatment of bacterial vaginosis is more effective than metronidazole alone. In addition, all patients taking Berberis vulgaris and metronidazole combination as their treatment were satisfied and did not experience recurrent infection during the three-week follow-up, while 12 patients $(30 \%)$ in the metronidazole group had trouble with recurrence during their follow-up. The results showed that the bacteria was grown in the plate containing Berberis 
vulgaris extract dilutions, from the dilution 1.25 to dilution 10 , but, in a dilution of 20, no bacteria was grown. MIC Berberis vulgaris extract for bacterial vaginalis is $20 \mathrm{mg}$ liter. Results related to antioxidant status, phenols, flavonoids, and flavonols in Berberis vulgaris extract in DPPH method was given.

Table 2. Comparison of bacterial vaginosis symptoms in two groups at the baseline

\begin{tabular}{|c|c|c|c|c|c|c|}
\hline \multirow{2}{*}{\multicolumn{2}{|c|}{ Variables }} & \multicolumn{2}{|c|}{ Metronidazole } & \multicolumn{2}{|c|}{ Berberis vulgaris and metronidazole } & \multirow[t]{2}{*}{$p$-value } \\
\hline & & $n$ & $\%$ & $n$ & $\%$ & \\
\hline \multirow[t]{2}{*}{ Burning } & Have & 27 & 67.5 & 21 & 52.5 & \multirow[t]{2}{*}{0.25} \\
\hline & Do not have & 13 & 32.5 & 19 & 47.5 & \\
\hline \multirow[t]{2}{*}{ Itching } & Have & 25 & 62.5 & 20 & 50 & \multirow[t]{2}{*}{0.36} \\
\hline & Do not have & 15 & $37 / 5$ & 20 & 50 & \\
\hline \multirow[t]{2}{*}{ Redness } & Have & 14 & 35 & 18 & 45 & \multirow[t]{2}{*}{0.49} \\
\hline & Do not have & 26 & 65 & 22 & 55 & \\
\hline \multirow[t]{2}{*}{ Dyspareunia } & Have & 16 & 40 & 18 & 45 & \multirow[t]{2}{*}{0.82} \\
\hline & Do not have & 24 & 60 & 22 & 55 & \\
\hline \multirow[t]{2}{*}{ Fever and shivering } & Have & 4 & 10 & 9 & 22.5 & \multirow[t]{2}{*}{0.22} \\
\hline & Do not have & 36 & 90 & 31 & .577 & \\
\hline \multirow[t]{2}{*}{ Dysuria } & Have & 14 & 35 & 16 & 35 & \multirow[t]{2}{*}{0.81} \\
\hline & Do not have & 26 & 65 & 24 & 65 & \\
\hline \multirow[t]{2}{*}{ Dysmenorrhea } & Have & 18 & 45 & 19 & 47.5 & \multirow[t]{2}{*}{0.98} \\
\hline & Do not have & 22 & 55 & 21 & 52.5 & \\
\hline
\end{tabular}

\section{Discussion}

The results of this study indicated high efficacy of metronidazole vaginal gel with Berberis vulgaris fruit extract $5 \%$, one applicator of $5 \mathrm{~g}$ daily for five consecutive nights for the treatment of bacterial vaginosis without causing any serious side effects. In this study, the improvement rate five days after the start of treatment, in the group of Berberis vulgaris and metronidazole, was higher than that of metronidazole alone. In addition, the relapse rate was $30 \%$ in the metronidazole group is consistent with the results of study by Sobel and colleagues (25.5\%) (29). This study is the first human study on the effect of metronidazole vaginal gel with extracts of Berberis vulgaris fruit extract in the treatment of bacterial vaginosis. However, laboratory studies have demonstrated antimicrobial effects of Berberis vulgaris extract. Berberis vulgaris fruits are effective in the treatment of bacterial vaginosis due to the different properties of its active ingredients contained in it, especially berberine, which has anti-inflammatory, antihistamine and anti-microbial effects. Studies carried out on the chemical composition of Berberis vulgaris has shown that the active ingredient of the plant are excenel including berberine, berbamin, and palmatine (30). Of them, berberine in Berberis vulgaris is one of the most important compounds that has anti-bacterial and anti-fungal properties. Studies have shown that this substance has an inhibitory effect on the growth of Candida albicans, Trichomoniasis vaginalis, and staphylococcus aureus (33). Han and his colleagues showed that the combination of amphotericin B and berberine can reduce the dose required of amphotericin up to $75 \%$ in the treatment of candidiasis (31). In a study by Soffar et al, it was concluded that berberine has similar effects with metronidazole in inhibiting the growth of Trichomoniasis vaginalis, and it can be replaced by this drug (32). The mechanism of action of berberine cause inhibition of A and B surtase. The inhibition of this enzyme significantly decreased virulence and infectivity of S. aureus and is proposed as antibacterial mechanism for berberine (33). In addition to the antimicrobial effects of this substance, berberine has analgesic and anti-inflammatory properties, while the main problem in the bacterial vaginosis is foul-smelling vaginal discharge, itching, burning, redness, dyspareunia, dysmenorrhea, fever, and shivering (34). Küpeli et al. proved in their study the analgesic and anti-inflammatory effects of berberine, which is the most effective compound in Berberis vulgaris (35). Analgesic and anti-inflammatory effects of berberine is likely to be related with prostaglandin E2 and decrease in cyclooxygenase (36). Shamsa and his colleagues showed in their study that Berberis vulgaris fruit has anti-histamine properties (37). Berberis vulgaris fruits contain vitamin $\mathrm{C}$ and acid addition compounds (38). Therefore, vitamin $\mathrm{C}$ and acidic environment of the vagina can help vaginosis treatment (38). The existence of vitamin $\mathrm{C}$ in the vagina reduces vaginal acidity and then can inhibit the growth of bacteria, which are not able to grow in an acidic environment. In addition, bacteria like lactobacilli that reproduce in the vagina acidic conditions, tend to grow and practically inhibited undesirable anaerobes growth strongly by acidic vitamin C compounds (39). A study by Miraj et al. demonstrated that vaginal gel consist of a Myrtus communis or Berberis vulgaris extract in metronidazole base is more effective than metronidazole gel alone and could be used as alternative option in medication resistance patients or patients with a trend to herbal medicine. Because Myrtus 
communis and Berberis vulgaris have antibacterial, antifungal, and anti-inflammatory effects, it seems necessary to conduct more studies to evaluate efficacy of these plants in treatment of bacterial and nonbacterial vaginitis (40).

\section{Conclusions}

Berberis vulgaris plus metronidazole vaginal gel was more effective than metronidazole gel alone in the treatment of patients with bacterial vaginosis as well as reduction of complaints and improvement of Amsel criteria and can be used as an appropriate treatment option in cases of drug resistance as well as people interested in treatment with the use of herbal medicines. The plant has antibacterial, antifungal, and anti-inflammatory properties; thus, it can be used in the treatment of diseases such as bacterial and nonbacterial vaginitis with further studies.

\section{Acknowledgments:}

This is part of an MD thesis dissertation supported by the Deputy of Research and Technology at Shahrekord University of Medical Sciences. We appreciate the patients and members of the hospital staff for their cooperation. The authors appreciate cooperation, technical, and financial support on the side of Shahrekord University of medical sciences.

Clinical trial registration: The trial was registered at the Iranian Registry of Clinical Trials (http://www.irct.ir) with the IRCT ID: IRCT201411102085N13.

Funding: Shahrekord University of Medical Sciences supported this research.

\section{Conflict of Interest:}

There is no conflict of interest to be declared.

\section{Authors' contributions:}

All authors contributed to this project and article equally. All authors read and approved the final manuscript.

\section{References:}

1) Seyyedi F, Rafiean-Kopaei M, Miraj S. Comparison of the Effects of Vaginal Royal Jelly and Vaginal Estrogen on Quality of Life, Sexual and Urinary Function in Postmenopausal Women. J Clin Diag Res. 2016; 10(5): 1-5. doi: 10.7860/jcdr/2016/17844.7715. PMID: 27437306, PMCID: PMC4948482.

2) Miraj S, Kiani S. Menstrual diseases as stated in canon fil-Tibb. Der Pharmacia Lettre. 2016; 8(6): 261-8.

3) Farage MA, Miller KW, Ledger WJ. Determining the cause of Vulvovaginal symptoms. Obstet Gynecol Surv. 2008; 63(7): 445-64. doi: 10.1097/OGX.0b013e318172ee25. PMID: 18559121.

4) Mashburn J. Vaginal infections update. J Midwifery Womens Health. 2012; 57(6): 629-34. doi: 10.1111/j.1542-2011.2012.00246.x. PMID: 23094602.

5) Burkman RT. Berek \& Novak’s Gynecology. JAMA. 2012; 613; 308(5): 516-7.

6) Cherpes TL, Hillier SL, Meyn LA, Busch JL, Krohn MA. A delicate balance: risk factors for acquisition of bacterial vaginosis include sexual activity, absence of hydrogen peroxide-producing lactobacilli, black race, and positive herpes simplex virus type 2 serology. Sex Transm Dis. 2008; 35(1): 78-83. doi: 10.1097/OLQ.0b013e318156a5d0. PMID: 17989585.

7) Reichman O, Akins R, Sobel JD. Boric acid addition to suppressive antimicrobial therapy for recurrent bacterial vaginosis. Sex Transm Dis. 2009; 36(11): 732-4. doi: 10.1097/OLQ.0b013e3181b08456. PMID: 19704395.

8) Allsworth JE. Bacterial vaginosis-race and sexual transmission: issues of causation. Sex Transm Dis. 2010; 37(3): 137-9. doi: 10.1097/OLQ.0b013e3181d36bdc. PMID: 20118829.

9) Ness RB, Hillier SL, Kip KE, Soper DE, Stamm CA, McGregor JA, et al. Bacterial vaginosis and risk of pelvic inflammatory disease. Obstet Gynecol. 2004; 104(4): 761-9. doi: 10.1097/01.AOG.0000139512.37582.17. PMID: 15458899.

10) Riggs M, Klebanoff M, Nansel T, Zhang J, Schwebke J, Andrews W. Longitudinal association between hormonal contraceptives and bacterial vaginosis in women of reproductive age. Sex Transm Dis. 2007; 34(12): 954-9. doi: 10.1097/OLQ.0b013e318074e565. PMID: 18077845.

11) Klebanoff MA, Nansel TR, Brotman RM, Zhang J, Yu KF, Schwebke JR, et al. Personal hygienic behaviors and bacterial vaginosis. Sex Transm Dis. 2010; 37(2): 94-9. doi: 10.1097/OLQ.0b013e3181bc063c. PMID: 19823112, PMCID: PMC2811217. 
12) Koumans EH, Sternberg M, Bruce C, McQuillan G, Kendrick J, Sutton M, et al. The prevalence of bacterial vaginosis in the United States, 2001-2004; associations with symptoms, sexual behaviors, and reproductive health. Sex Transm Dis. 2007; 34(11): 864-9. PMID: 17621244.

13) Schwebke JR, Desmond RA, Oh MK. Predictors of bacterial vaginosis in adolescent women who douche. Sex Transm Dis. 2004; 31(7): 433-6. PMID: 15215700.

14) Bilardi JE, Walker S, Temple-Smith M, McNair R, Mooney-Somers J, Bellhouse C, et al. The burden of bacterial vaginosis: women's experience of the physical, emotional, sexual and social impact of living with recurrent bacterial vaginosis. PloS one. 2013; 8(9): e74378. doi: 10.1371/journal.pone.0074378. PMID: 24040236, PMCID: PMC3770676.

15) de Figueiredo Leite SR, de Amorim MM, Calábria WB, de Figueiredo Leite TN, de Oliveira VS, Ferreira Júnior JA, et al. [Clinical and microbiological profile of women with bacterial vaginosis]. Rev Bras Ginecol Obstet. 2010; 32(2): 82-7. PMID: 20305946.

16) Donders GG, Zodzika J, Rezeberga D. Treatment of bacterial vaginosis: what we have and what we miss. Expert Opin Pharmacother. 2014; 15(5): 645-57. doi: 10.1517/14656566.2014.881800. PMID: 24579850.

17) Verstraelen H, Verhelst R. Bacterial vaginosis: an update on diagnosis and treatment. Expert Rev Anti Infect Ther. 2009; 7(9): 1109-24. doi: 10.1586/eri.09.87. PMID: 19883331.

18) Löfmark S, Edlund C, Nord CE. Metronidazole is still the drug of choice for treatment of anaerobic infections. Clin Infect Dis. 2010; 50(Suppl 1): 16-23. doi: 10.1086/647939. PMID: 20067388.

19) Ferris DG, Litaker MS, Woodward L, Mathis D, Hendrich J. Treatment of bacterial vaginosis: a comparison of oral metronidazole, metronidazole vaginal gel, and clindamycin vaginal cream. J Fam Pract. 1995; 41(5): 443-9. PMID: 7595261.

20) Rafiean-Kopaei M, Baradaran A, Maghsoudi AR, Ghobadi Sh, Nasri H. Helicobacter pylori infection and serum homocysteine in hemodialysis patient. Life Sci J. 2012; 9(4): 3696-3702.

21) Sharafati-chaleshtori R, Rafieian-kopaei M. Screening of antibacterial effect of the Scrophularia Striata against E. coli in vitro. J HerbMed Pharmacol. 2014; 3(1): 31-4.

22) Amirmohammadi M, Khajoenia S, Bahmani M, Rafieian-Kopaei M, Eftekhari Z, Qorbani M. In vivo evaluation of antiparasitic effects of Artemisia abrotanum and Salvia officinalis extracts on Syphacia obvelata, Aspiculoris tetrapetra and Hymenolepis nana parasites. Asian Pac J Trop Dis. 2014; 4(1): 250254. doi: 10.1016/S2222-1808(14)60449-7.

23) Bahmani M, Rafieian-Kopaei M. Medicinal plants and secondary metabolites for leech control. Asian Pac J Trop Dis. 2014; 4(4): 315-6. doi: 10.1016/S2222-1808(14)60580-6.

24) Shirzad H, Taji F, Rafieian-Kopaei M. Correlation between antioxidant activity of garlic extracts and WEHI-164 fibrosarcoma tumor growth in BALB/c mice. J Med Food. 2011; 14(9): 969-74. doi: 10.1089/jmf.2011.1594. PMID: 21812650.

25) Ghasemi Dehkordi N.A, Sajadi S.E, Ghanadi A.R, Amanzadeh Y, Azadbakht M, Asghari GH.R, et al. Iranian herbal pharmacopoeia (IHP). HAKIM. 2003; 6(3): 63-9.

26) Sobel JD. Bacterial vaginosis. Annu Rev Med. 2000; 51: 349-56. doi: 10.1146/annurev.med.51.1.349. PMID: 10774469.

27) Simbar M, Azarbad Z, Mojab F, Majd HA. A comparative study of the therapeutic effects of the Zataria multiflora vaginal cream and metronidazole vaginal gel on bacterial vaginosis. Phytomedicine. 2008; 15(12): 1025-31. doi: 10.1016/j.phymed.2008.08.004. PMID: 18824338.

28) Rabiei Z, Rafieian-Kopaei M, Heidarian E, Saghaei E, Mokhtari S. Effects of Zizyphus jujube extract on memory and learning impairment induced by bilateral electric lesions of the nucleus Basalis of Meynert in rat. Neurochem Res. 2014; 39(2): 353-60. doi: 10.1007/s11064-013-1232-8. PMID: 24379110.

29) Sobel JD, Ferris D, Schwebke J, Nyirjesy P, Wiesenfeld HC, Peipert J, et al. Suppressive antibacterial therapy with $0.75 \%$ metronidazole vaginal gel to prevent recurrent bacterial vaginosis. Am J Obstet Gynecol. 2006; 194(5): 1283-9. doi: 10.1016/j.ajog.2005.11.041. PMID: 16647911.

30) Imanshahidi $M$, Hosseinzadeh $H$. Pharmacological and therapeutic effects of Berberis vulgaris and its active constituent, berberine. Phytother Res. 2008; 22(8): 999-1012. doi: 10.1002/ptr.2399. PMID: 18618524.

31) Han Y, Lee JH. Berberine synergy with amphotericin B against disseminated candidiasis in mice. Biol Pharm Bull. 2005; 28(3): 541-4. PMID: 15744087.

32) Soffar SA, Metwali DM, Abdel-Aziz SS, el-Wakil HS, Saad GA. Evaluation of the effect of a plant alkaloid (berberine derived from Berberis aristata) on Trichomonas vaginalis in vitro. J Egypt Soc Parasitol. 2001; 31(3): 893-904. PMID: 11775115. 
33) Oh KB, Oh MN, Kim JG, Shin DS, Shin J. Inhibition of sortase-mediated Staphylococcus aureus adhesion to fibronectin via fibronectin-binding protein by sortase inhibitors. Appl Microbiol Biotechnol. 2006; 70(1): 102-6. PMID: 16010573.

34) Danforth DN, Gibbs RS. Danforth's obstetrics and gynecology: Lippincott Williams \& Wilkins; $2008: 783$.

35) Kupeli E, Kosar M, Yesilada E, Husnu K, Baser C. A comparative study on the anti-inflammatory, antinociceptive and antipyretic effects of isoquinoline alkaloids from the roots of Turkish Berberis species. Life sciences. 2002; 72(6): 645-57. PMID: 12467905.

36) Kuo CL, Chi CW, Liu TY. Modulation of apoptosis by berberine through inhibition of cyclooxygenase-2 and Mcl-1 expression in oral cancer cells. In vivo. 2005; 19(1): 247-52. PMID: 15796182.

37) Shamsa F, Ahmadiani A, Khosrokhavar R. Antihistaminic and anticholinergic activity of Berberis vulgaris fruit (Berberis vulgaris) in the guinea-pig ileum. J Ethnopharmacol. 1999; 64(2): 161-6. PMID: 10197751.

38) Godarzi F, Abaspour Z, Abaspour MR, Momeni A, Zandi K. The Effect of Vitamin C Vaginal Tablets on Amsel Criterion in Patients with Bacterial Vaginosis. Armaghane Danesh. 2011; 16(4): 372-80.

39) Petersen EE, Magnani P. Efficacy and safety of Vitamin C vaginal tablets in the treatment of non-specific vaginitis: A randomised, double blind, placebo-controlled study. Eur J Obstet Gynecol Reprod Biol. 2004; 117(1): 70-5. doi: 10.1016/j.ejogrb.2004.02.032. PMID: 15474248.

40) Masoudi M, Miraj S, Rafieian-Kopaei M. Comparison of the Effects of Myrtus Communis L, Berberis Vulgaris and Metronidazole Vaginal Gel alone for the Treatment of Bacterial Vaginosis. J Clin Diagn Res. 2016; 10(3): 4-7. doi: 10.7860/JCDR/2016/17211.7392. PMID: 27134945, PMCID: PMC4843330

41) Seyyedi F, Rafiean-Kopaei M, Miraj S. Comparison of the Effects of Vaginal Royal Jelly and Vaginal Estrogen on Quality of Life, Sexual and Urinary Function in Postmenopausal Women. J Clin Diag Res. 2016; 10(5): 1-5. doi: 10.7860/jcdr/2016/17844.7715. PMID: 27437306, PMCID: PMC4948482.

42) Miraj S, Kiani S. Menstrual diseases as stated in canon fil-Tibb. Der Pharmacia Lettre. 2016; 8(6): 261-8.

43) Farage MA, Miller KW, Ledger WJ. Determining the cause of Vulvovaginal symptoms. Obstet Gynecol Surv. 2008; 63(7): 445-64. doi: 10.1097/OGX.0b013e318172ee25. PMID: 18559121.

44) Mashburn J. Vaginal infections update. J Midwifery Womens Health. 2012; 57(6): 629-34. doi: 10.1111/j.1542-2011.2012.00246.x. PMID: 23094602.

45) Burkman RT. Berek \& Novak’s Gynecology. JAMA. 2012; 613; 308(5): 516-7.

46) Cherpes TL, Hillier SL, Meyn LA, Busch JL, Krohn MA. A delicate balance: risk factors for acquisition of bacterial vaginosis include sexual activity, absence of hydrogen peroxide-producing lactobacilli, black race, and positive herpes simplex virus type 2 serology. Sex Transm Dis. 2008; 35(1): 78-83. doi: 10.1097/OLQ.0b013e318156a5d0. PMID: 17989585.

47) Reichman O, Akins R, Sobel JD. Boric acid addition to suppressive antimicrobial therapy for recurrent bacterial vaginosis. Sex Transm Dis. 2009; 36(11): 732-4. doi: 10.1097/OLQ.0b013e3181b08456. PMID: 19704395.

48) Allsworth JE. Bacterial vaginosis-race and sexual transmission: issues of causation. Sex Transm Dis. 2010; 37(3): 137-9. doi: 10.1097/OLQ.0b013e3181d36bdc. PMID: 20118829.

49) Ness RB, Hillier SL, Kip KE, Soper DE, Stamm CA, McGregor JA, et al. Bacterial vaginosis and risk of pelvic inflammatory disease. Obstet Gynecol. 2004; 104(4): 761-9. doi: 10.1097/01.AOG.0000139512.37582.17. PMID: 15458899.

50) Riggs M, Klebanoff M, Nansel T, Zhang J, Schwebke J, Andrews W. Longitudinal association between hormonal contraceptives and bacterial vaginosis in women of reproductive age. Sex Transm Dis. 2007; 34(12): 954-9. doi: 10.1097/OLQ.0b013e318074e565. PMID: 18077845.

51) Klebanoff MA, Nansel TR, Brotman RM, Zhang J, Yu KF, Schwebke JR, et al. Personal hygienic behaviors and bacterial vaginosis. Sex Transm Dis. 2010; 37(2): 94-9. doi: 10.1097/OLQ.0b013e3181bc063c. PMID: 19823112, PMCID: PMC2811217.

52) Koumans EH, Sternberg M, Bruce C, McQuillan G, Kendrick J, Sutton M, et al. The prevalence of bacterial vaginosis in the United States, 2001-2004; associations with symptoms, sexual behaviors, and reproductive health. Sex Transm Dis. 2007; 34(11): 864-9. PMID: 17621244.

53) Schwebke JR, Desmond RA, Oh MK. Predictors of bacterial vaginosis in adolescent women who douche. Sex Transm Dis. 2004; 31(7): 433-6. PMID: 15215700.

54) Bilardi JE, Walker S, Temple-Smith M, McNair R, Mooney-Somers J, Bellhouse C, et al. The burden of bacterial vaginosis: women's experience of the physical, emotional, sexual and social impact of living with recurrent bacterial vaginosis. PloS one. 2013; 8(9): e74378. doi: 10.1371/journal.pone.0074378. PMID: 24040236, PMCID: PMC3770676. 
55) de Figueiredo Leite SR, de Amorim MM, Calábria WB, de Figueiredo Leite TN, de Oliveira VS, Ferreira Júnior JA, et al. [Clinical and microbiological profile of women with bacterial vaginosis]. Rev Bras Ginecol Obstet. 2010; 32(2): 82-7. PMID: 20305946.

56) Donders GG, Zodzika J, Rezeberga D. Treatment of bacterial vaginosis: what we have and what we miss. Expert Opin Pharmacother. 2014; 15(5): 645-57. doi: 10.1517/14656566.2014.881800. PMID: 24579850.

57) Verstraelen $H$, Verhelst R. Bacterial vaginosis: an update on diagnosis and treatment. Expert Rev Anti Infect Ther. 2009; 7(9): 1109-24. doi: 10.1586/eri.09.87. PMID: 19883331.

58) Löfmark S, Edlund C, Nord CE. Metronidazole is still the drug of choice for treatment of anaerobic infections. Clin Infect Dis. 2010; 50(Suppl 1): 16-23. doi: 10.1086/647939. PMID: 20067388.

59) Ferris DG, Litaker MS, Woodward L, Mathis D, Hendrich J. Treatment of bacterial vaginosis: a comparison of oral metronidazole, metronidazole vaginal gel, and clindamycin vaginal cream. J Fam Pract. 1995; 41(5): 443-9. PMID: 7595261.

60) Rafiean-Kopaei M, Baradaran A, Maghsoudi AR, Ghobadi Sh, Nasri H. Helicobacter pylori infection and serum homocysteine in hemodialysis patient. Life Sci J. 2012; 9(4): 3696-3702.

61) Sharafati-chaleshtori R, Rafieian-kopaei M. Screening of antibacterial effect of the Scrophularia Striata against E. coli in vitro. J HerbMed Pharmacol. 2014; 3(1): 31-4.

62) Amirmohammadi M, Khajoenia S, Bahmani M, Rafieian-Kopaei M, Eftekhari Z, Qorbani M. In vivo evaluation of antiparasitic effects of Artemisia abrotanum and Salvia officinalis extracts on Syphacia obvelata, Aspiculoris tetrapetra and Hymenolepis nana parasites. Asian Pac J Trop Dis. 2014; 4(1): 250 254. doi: 10.1016/S2222-1808(14)60449-7.

63) Bahmani M, Rafieian-Kopaei M. Medicinal plants and secondary metabolites for leech control. Asian Pac J Trop Dis. 2014; 4(4): 315-6. doi: 10.1016/S2222-1808(14)60580-6.

64) Shirzad H, Taji F, Rafieian-Kopaei M. Correlation between antioxidant activity of garlic extracts and WEHI-164 fibrosarcoma tumor growth in BALB/c mice. J Med Food. 2011; 14(9): 969-74. doi: 10.1089/jmf.2011.1594. PMID: 21812650.

65) Ghasemi Dehkordi N.A, Sajadi S.E, Ghanadi A.R, Amanzadeh Y, Azadbakht M, Asghari GH.R, et al. Iranian herbal pharmacopoeia (IHP). HAKIM. 2003; 6(3): 63-9.

66) Sobel JD. Bacterial vaginosis. Annu Rev Med. 2000; 51: 349-56. doi: 10.1146/annurev.med.51.1.349. PMID: 10774469.

67) Simbar M, Azarbad Z, Mojab F, Majd HA. A comparative study of the therapeutic effects of the Zataria multiflora vaginal cream and metronidazole vaginal gel on bacterial vaginosis. Phytomedicine. 2008; 15(12): 1025-31. doi: 10.1016/j.phymed.2008.08.004. PMID: 18824338.

68) Rabiei Z, Rafieian-Kopaei M, Heidarian E, Saghaei E, Mokhtari S. Effects of Zizyphus jujube extract on memory and learning impairment induced by bilateral electric lesions of the nucleus Basalis of Meynert in rat. Neurochem Res. 2014; 39(2): 353-60. doi: 10.1007/s11064-013-1232-8. PMID: 24379110.

69) Sobel JD, Ferris D, Schwebke J, Nyirjesy P, Wiesenfeld HC, Peipert J, et al. Suppressive antibacterial therapy with $0.75 \%$ metronidazole vaginal gel to prevent recurrent bacterial vaginosis. Am J Obstet Gynecol. 2006; 194(5): 1283-9. doi: 10.1016/j.ajog.2005.11.041. PMID: 16647911.

70) Imanshahidi M, Hosseinzadeh $H$. Pharmacological and therapeutic effects of Berberis vulgaris and its active constituent, berberine. Phytother Res. 2008; 22(8): 999-1012. doi: 10.1002/ptr.2399. PMID: 18618524.

71) Han Y, Lee JH. Berberine synergy with amphotericin B against disseminated candidiasis in mice. Biol Pharm Bull. 2005; 28(3): 541-4. PMID: 15744087.

72) Soffar SA, Metwali DM, Abdel-Aziz SS, el-Wakil HS, Saad GA. Evaluation of the effect of a plant alkaloid (berberine derived from Berberis aristata) on Trichomonas vaginalis in vitro. J Egypt Soc Parasitol. 2001; 31(3): 893-904. PMID: 11775115.

73) Oh KB, Oh MN, Kim JG, Shin DS, Shin J. Inhibition of sortase-mediated Staphylococcus aureus adhesion to fibronectin via fibronectin-binding protein by sortase inhibitors. Appl Microbiol Biotechnol. 2006; 70(1): 102-6. PMID: 16010573.

74) Danforth DN, Gibbs RS. Danforth's obstetrics and gynecology: Lippincott Williams \& Wilkins; 2008: 783.

75) Kupeli E, Kosar M, Yesilada E, Husnu K, Baser C. A comparative study on the anti-inflammatory, antinociceptive and antipyretic effects of isoquinoline alkaloids from the roots of Turkish Berberis species. Life sciences. 2002; 72(6): 645-57. PMID: 12467905.

76) Kuo CL, Chi CW, Liu TY. Modulation of apoptosis by berberine through inhibition of cyclooxygenase-2 and Mcl-1 expression in oral cancer cells. In vivo. 2005; 19(1): 247-52. PMID: 15796182. 
77) Shamsa F, Ahmadiani A, Khosrokhavar R. Antihistaminic and anticholinergic activity of Berberis vulgaris fruit (Berberis vulgaris) in the guinea-pig ileum. J Ethnopharmacol. 1999; 64(2): 161-6. PMID: 10197751.

78) Godarzi F, Abaspour Z, Abaspour MR, Momeni A, Zandi K. The Effect of Vitamin C Vaginal Tablets on Amsel Criterion in Patients with Bacterial Vaginosis. Armaghane Danesh. 2011; 16(4): 372-80.

79) Petersen EE, Magnani P. Efficacy and safety of Vitamin C vaginal tablets in the treatment of non-specific vaginitis: A randomised, double blind, placebo-controlled study. Eur J Obstet Gynecol Reprod Biol. 2004; 117(1): 70-5. doi: 10.1016/j.ejogrb.2004.02.032. PMID: 15474248.

80) Masoudi M, Miraj S, Rafieian-Kopaei M. Comparison of the Effects of Myrtus Communis L, Berberis Vulgaris and Metronidazole Vaginal Gel alone for the Treatment of Bacterial Vaginosis. J Clin Diagn Res. 2016; 10(3): 4-7. doi: 10.7860/JCDR/2016/17211.7392. PMID: 27134945, PMCID: PMC4843330 